\title{
Implementasi Kebijakan Pencegahan Dan Penanganan Covid-19 Di Pondok Pesantren Modern Selamat Kabupaten Kendal, Jawa Tengah
}

\author{
Luth $^{1}$, Meriwijaya ${ }^{2}$ \\ 1Universitas Selamat Sri, Kendal, Jawa Tengah \\ 2Universitas Selamat Sri, Kendal, Jawa Tengah \\ E-mail: litfiaswar@gmail.com
}

\begin{abstract}
Abstrak; Penelitian tentang Implementasi Kebijakan Pencegahan dan Penanganan Covid-19 Di Lingkungan Pondok Pesantren Modern Selamat merupakan penelitian yang dilatarbelakangi oleh adanya penemuan kasus penyebaran Covid-19 klaster pondok pesantren yang menimpa Pondon Pesantren Modern Selamat namun dengan berbagai upaya pencegahan dan penanganan yang dilakukan, Pondok Pesantren Modern Selamat ditunjuk sebagai pondok dengan pengalaman terbaik penanganan covid-19 se-Jawa Tengah oleh yayasan Setara bekerjasama dengan Lembaga Penelitian dan Pengabdian Kepada Masyarakat Universitas Diponegoro (LPPM Undip) dan Unicef Jawa Tengah. Metode yang digunakan pada penelitian ini adalah deskriftip kualitatif dengan berpedoman pada konsep-konsep studi kepustakaan dan wawancara. Tujuan penelitian ini adalah untuk menggambarkan serta menganalisa tentang Implementasi Kebijakan Pencegahan dan Penanganan Covid-19 di Lingkungan Pondok Pesantren Modern Selamat. Hasil dari penelitian ini: Pertama, menghentikan laju penyebaran dan transmisi/penularan Covid-19 dengan upaya perlindungan kesehatan yang terbagi menjadi: Upaya pencegahan dengan kegiatan promosi kesehatan, kegiatan perlindungan dengan menyediakan fasilitas yang sesuai dengan protokol kesehatan Covid-19, Upaya penemuan kasus (detect) dengan cara melakukan pemeriksaan suhu tubuh dan swab test, Serta penerapan penanganan secara cepat dan efektif dengan cara pembatasan pisik dan pembatasan sosial, penerapan etika batuk dan bersin, isolasi mandiri, dan pelaksanaan tindakan karantina. Kedua, menyediakan fasilitas pelayanan kesehatan diantaranya: rumah karantina, ruang isolasi dan ruang pemeriksaan kesehatan. Ketiga, Meminimalisir dampak dari pandemi Covid-19 terhadap pelayanan sosial dengan cara menutup akses menuju pondok Pesantren Modern Selamat, menyedikan fasilitas yang dilengkapi dengan protokol kesehatan, melakukan pemeriksaan berkala terhadap semua SDM yang ada di lingkungan Pondok Pesantren Modern Selamat.

Kata kunci: Implementasi Kebijakan, Pencegahan dan Penanganan, Covid-19
\end{abstract}

Abstract: Research on the Implementation of Covid-19 Prevention and Management Policies in the Modern Selamat Pondok Pesantren is a research based on the discovery of cases of the spread of Covid-19 in the Islamic boarding school cluster that hit Pondon Pesantren Modern Selamat but with various prevention and handling efforts carried out, Pondok Pesantren Modern Congratulations on being appointed as the lodge with the best experience in handling covid-19 in Central Java by the Setara foundation in collaboration with the Diponegoro University Research and Community Service Institute (LPPM Undip) and Central Java Unicef. The method used in this research is descriptive qualitative based on the concepts of literature study and interviews. The purpose of this study is to describe and analyze the implementation of policies for the prevention and handling of Covid-19 in the Modern Selamat Pondok Pesantren. The results of this study: First, stop the spread and transmission/ transmission rate of Covid-19 with health protection efforts which are divided into: Prevention efforts with health promotion activities, protection activities by providing facilities in accordance with the Covid-19 health protocol, Case finding efforts ( detect) by carrying out body temperature checks and swab tests, as well as implementing fast and effective treatment by means of physical restrictions and social restrictions, application of cough and sneezing ethics, self-isolation, and implementation of quarantine measures. Second, providing health service facilities including: quarantine houses, isolation rooms and medical examination rooms. Third, minimize the impact of the Covid-19 pandemic on social services by closing access to the Modern Selamat Islamic Boarding School, providing facilities equipped with health protocols, conducting periodic checks on all human resources in the Modern Selamat Pondok Pesantren.

Keywords: Policy Implementation, Prevention and Handling, Covid-19 


\section{Pendahuluan}

Adanya Covid-19 yang muncul pada awal tahun 2020 sangat berdampak terhadap berbagai sektor, termasuk sektor pendidikan. Badan kesehatan Dunia/ Word Health Organization (WHO) pada tanggal 11 Maret 2020 menetapkan Covid-19 menjadi masalah kesehatan global yang kemudian ditetapkan sebagai pandemi. Setelah pengumuman kasus pertama adanya penularan covid-19 di Indonesia, fakta menunjukkan bahwa jumlah kasus positif covid-19 (Corona) mencapai 69 orang dalam jangka waktu 11 hari dengan 4 orang diantaranya meninggal dunia. Dengan adanya kondisi tersebut, berbagai upaya serta kebijakan yang dikeluarkan pemerintah dalam melakukan pencegahan dan penanganan terhadap potensi penyebaran pandemi covid-19. Secara singkat Thomas R Dye (dalam Edi Suharto, 2010:44) menyatakan bahwa kebijakan publik adalah apapun yang dipilih oleh pemerintah untuk dilakukan ataupun untuk tidak dilakukan. Sementara itu Anderson (dalam Edi Suharto, 2010:44) menyatakan secara lebih spesifik bahwa kebijakan publik sebagai sebuah jalan aksi yang sengaja diambil oleh seorang aktor atau sejumlah aktor dalam menyelesaikan satu masalah atau sejumlah fokus permasalahan. Berkaitan dengan kebijakan tersebut, pada tanggal 13 Maret 2020 Presiden menandatangani Keputusan Presiden Nomor 7 Tahun 2020 tentang Gugus Tugas Percepatan Penanganan Covid-19. Sebagaimana dikutip dari kompaspedia.kompas.id (2020, 22 Juni). Upaya dan Kebijakan Pemerintah Indonesia Menangani Pandemi Covid-19. Diakses pada 5 Mei 2021, dari: https://kompaspedia.kompas.id/baca/paparan-topik/upaya-dan-kebijakan-pemerintahindonesia-menangani-pandemi-covid-19. Langkah strategis segera diambil pemerintah terutama dalam bidang kesehatan diantaranya melakukan penambahan rumah sakit rujukan covid-19 yang pada awalnya disiapkan 100 rumah sakit ditambah menjadi 132 Rumah Sakit pemerintah, 109 Rumah Sakit milik TNI, 53 Rumah Sakit Polri dan 65 Rumah Sakit BUMN.

Masih dikutip dari halaman website yang sama, langkah selanjutnya yang diambil pemerintah yaitu sejak tanggal 15 Maret 2020, Presiden meminta pemerintah daerah untuk membuat kebijakan mengenai pembatasan aktifitas dibidang pendidikan yaitu kebijakan belajar dari rumah. Selain itu, Pemerintah menetapkan peraturan tentang Pembatasan Sosial Bersekala Besar melalui Peraturan Pemerintah (PP) Nomor 21 Tahun 2020 Tentang Pembatasan Sosial Bersekala Besar (PSBB) dalam Rangka Percepatan Penanganan Covid-19 dan Keputusan Presiden Nomor 11 Tahun 2020 tentang Penetapan Kedaruratan Kesehatan Masyarakat Covid-19. Mekanisme dan indikator penerapan PSBB di tingkat daerah diatur secara rinci dalam Peraturan Menteri Kesehatan Nomor 9 Tahun 2020 tentang Pedoman Pembatasan Sosial Bersekala Besar dan Rangka Percepatan Penanganan Covid-19. Adapun daerah yang pertama mengajukan PSBB adalah Provinsi DKI Jakarta sebagai wiayah terdampak covid-19 paling tinggi dibanding daerah-daerah lainnya. Pengajuan PSBB DKI Jakarta distujui oleh Kementerian Kesehatan dengan dikeluarkan Keputusan Menteri Kesehatan menganai PSBB di Wilayah Provinsi DKI Jakarta 
dalam rangka Percepatan Penanganan Covid-19 yang ditandatangani Oleh Menteri Kesehatan pada tanggal 7 April 2020. Keputusan Menteri Kesehatan ini kemudian disusul dengan Keputusan Gubernur DKI Jakarat Nomor 380 Tahun 2020 Tentang Pemberlakuan Pelaksanaan Pembatasan Sosial Bersekala Besar (PSBB) dalam penanganan Corona Virus Disease 2019 (COVID-19) di Provinsi DKI Jakarta.

Dalam rangka menyikapi kondisi yang terjadi, Pemerintah Kabupaten Kendal, Jawa Tengah membuat berbagai kebijkan sebagai upaya pencegahan dan penanganan penyebaran Covid-19. Sebagaimana dikutip dari halaman website jatengprov.go.id (2020, 30 Juni). Program Inovasi di Kabupaten Kendal Kurangi Penyebaran Covid-19. Diakses pada 6 Mei 2021, dari: https://jatengprov.go.id/beritadaerah/program-inovasi-di-kabupatenkendal-kurangi-penyebaran-covid-19/ disebutkan bahwa dalam upaya pencegahan dan penanganan covid-19 Pemerintah Kabupaten Kendal mempunyai beberapa program inovasi Smart City yang bermanfaat di tengah pandemi Covid-19 diantaranya Mall Online (marketplace) yang bermanfaat dalam membantu bidang pendapatan masyarakat, pendidikan dengan e-book, Serta bidang kesehatan dengan aplikasi yankes online. Serta berbagai kebijakan diantaranya Perbup Nomor 51 Tahun 2020 Tentang Kewajiban Penggunaan Masker Dan Jaga Jarak Fisik, Surat Edaran (SE) Panduan Penyelenggaraan Kegiatan keagamaan, SE Pembatasan Aktifitas Kegiatan Bagi Pelaku Usaha, dan SE Himbauan Pembatasan Aktivitas Kegiatan Masyarakat.

Permasalahan yang muncul kemudian adalah adanya kebijakan pemberlakuan Era Normal Baru Pasca Covid-19 (New Normal) dengan dibukanya akses terhadap berbagai sektor mengakibatkan angka penyebaran Covid-19 kembali meningkat. Munculnya Klaster Pesantren dan Sekolah di Jawa tengah menjadi salah satu sektor yang mengakibatkan meningkatnya persebaran Covid-19. Sebagaimana dikutip dari halaman website republika.co.id (2020, 14 Oktober). Klaster Pesantren dan Sekolah Yang Mengancam Jawa Tengah. Diakses pada 6 Mei 2021, dari: https://www.republika.co.id/berita/qi6iel328/klaster-pesantren-dan-sekolah-yangmengancam-jawa-tengah. terdapat 648 kasus penyebaran covid-19 pada klaster Pondok Pesantren dan Sekolah yang tersebar di Kabupaten Banyumas, Kendal, tegal dan beberapa kabupaten lainnya. Salah satu klaster pondok pesantren tersebut adalah Klaster Pondok Pesantren Modern Selamat di Desa Jambearum, Kecamatan Patebon, Kabupaten kendal dengan 13 santri terkonfirmasi positif terpapar Covid-19 ( radarsemarang.jawapos.com. 2020, 22 September. Klaster Ponpes, 16 Posistiv Covid-19. Diakses pada 6 Mei 2020, dari: https://radarsemarang.jawapos.com/berita/jateng/kendal/2020/09/22/klaster-ponpes16-positif-covid-19/). Dibalik permasalahan adanya sebaran covid-19 Klaster Pondok Pesantren yang menimpa Pondok Modern Selamat, setelah berbagai upaya pencegahan dan penanganan terhadap penularan Covid-19, Pondok Pesantren Modern Selamat justru ditunjuk sebagai pondok dengan pengalaman terbaik penanganan covid-19 se-Jawa Tengah 
oleh yayasan Setara bekerjasama dengan Lembaga Penelitian dan Pengabdian Kepada Masyarakat Universitas Diponegoro (LPPM Undip) dan Unicef Jawa Tengah. Adapun strategi dan indikator penanggulangan pandemi berdasarkan buku pedoman pencegahan dan pengendalian Corona Virus Disease (Covid-19) Revisi Ke-5 yang diterbitkan oleh Kementrian Kesehatan Republik Indonesia pada tanggal 13 Juli 2020 disebutkan bahwa strategi penanggulangan sesuai dengan transmisi yang terjadi baik di tingkat nasional maupun provinsi, dengan tujuan: Pertama, memperlambat dan menghentikan laju transmisi/penularan, dan menunda penyebaran penularan. Kedua, menyediakan pelayanan kesehatan yang optimal untuk pasien, terutama kasus kritis, dan Ketiga, meminimalkan dampak dari pandemi COVID-19 terhadap sistem kesehatan, pelayanan sosial, kegiatan di bidang ekonomi, dan kegiatan sektor lainnya.

Berangkat dari fakta dan berbagai permasalahan yang telah diuraikan di atas, peneliti bermaksud untuk melakukan penelitian mengenai Implementasi Kebijakan Pencegahan Dan Penanganan Covid-19 Di Pondok Pesantren Modern Selamat Kabupaten Kendal, Jawa Tengah dengan tujuan penelitian untuk menggambarkan dan menganalisa tentang Implementasi Kebijakan Pencegahan Dan Penanganan Covid-19 Di Pondok Pesantren Modern Selamat Kabupaten Kendal, Jawa Tengah, sehingga hasil penelitian ini diharapkan dapat bermanfaat dalam memberikan masukan untuk penambahan pengetahuan serta memperkaya khasanah kajian tentang pencegahan dan penanganan Covid-19, menjadi bahan rujukan pengambilan keputusan serta memberi kontribusi informasi bagi semua pihak dalam melakukan pencegahan dan penanganan Covid-19, dan dapat dijadikan referensi atau pedoman bagi penelitian selanjutnya tentang pencegahan dan penanganan Covid-19.

\section{Metode Penelitian}

Dalam penelitian ini penulis menggunakan metode deskriptif kualitatif yaitu membuat gambaran secara sistematis, faktual dan akurat mengenai fakta-fakta dan sifatsifat dari populasi atau daerah tertentu yang dijadikan objek atau subjek penelitian, sehingga dengan gambaran tersebut menghasilkan suatu pemikiran tentang pencegahan dan penanganan Covid-19 yang dapat diamati secara langsung pada saat penelitian dilakukan. Dalam metode ini analisis dilakukan pada identifikasi masalah dan penjabaran terhadap data yang dikumpulkan dengan berpedoman pada konsep-konsep studi kepustakaan yang relevan. Menurut M. Nazir dalam bukunya yang berjudul "Metode Penelitian" mengemukakan bahwa yang dimaksud dengan: Studi kepustakaan adalah teknik pengumpulan data dengan mengadakan studi penelaahan terhadap buku-buku, literatur-literatur, catatan-catatan, dan laporan-laporan yang ada hubungannya dengan masalah yang dipecahkan. Selanjutnya menurut Nazir (1998 : 112) studi kepustakaan merupakan langkah yang penting dimana setelah seorang peneliti menetapkan topic 
penelitian, langkah selanjutnya adalah melakukan kajian yang berkaitan dengan teori yang berkaitan dengan topik penelitian. Dalam pencarian teori, peneliti akan mengumpulkan informasi sebanyak-banyaknya dari kepustakaan yang berhubungan. Sumber-sumber kepustakaan dapat diperoleh dari: buku, jurnal, majalah, hasil-hasil penelitian (tesis dan disertasi), dan sumber-sumber lainnya yang sesuai (internet, koran dll). Selain studi kepustakaan, peneliti juga melakukan wawancara terhadap beberapa nara sumber yang berasal dari para pejabat struktural di Pondok Pesantren Modern Selamat sehingga dihasilkan deskripsi atau gambaran secara sistematis, faktual, dan akurat mengenai Implementasi Kebijakan Pencegahan Dan Penanganan Covid-19 Di Pondok Pesantren Modern Selamat Kabupaten Kendal, Jawa Tengah.

\section{Hasil Penelitian}

Hasil penelitian Implementasi Kebijakan Pencegahan dan Penanganan Covid 19 Di Pondok Pesantren Modern Selamat Kabupaten Kendal, Jawa Tengah secara terperinci sebagai berikut:

\section{a. Profil Objek Penelitian}

Pondok Pesantren Modern Selamat Kendal atau yang biasa disingkat PMS merupakan pondok yang berdiri dibawah naungan Yayasan Wakaf Selamat Rahayu Kendal. Sebagai pondok yang mengutamakan pendidikan akademik dan religi, maka sistem pengajaran yang digunakan menggunakan dua kurikulum yaitu dari Pendidikan Nasional dan Departemen Agama. Saat ini, jumlah santri Pondok Modern Selamat lebih dari 2000 Orang.

Pondok Pesantren Modern Selamat Kendal didirikan sejak tahun 1992 oleh H. Selamat Soemadyo. Pondok ini berbasi lembaga pendidikan formal disertai pendidikan agama dengan salah satu tujuan yaitu membentuk anak didik yang berakhlatul karimah yang dapat hidup di tengah laju perkembangan ilmu pengetahuan dan teknologi.

Pondok Modern Selamat memiliki dua kampus dengan lokasi yang berbeda. Lokasi yang pertama berada di Jl. Soekarno-Hatta Km. 3 Desa Jambearum, kec. Patebon, Kabupaten kendal. Lokasi kedua beralamat di Jl. Raya Batang-Semarang Km. 14 Desa Clapar Kec. Subah, Kabupaten Batang, Jawa Tengah dengan luas kedua lokasi tersebut lebih dari 40 Hektar. Adapun bidang pendidikan yang ada di Pondok Pesantren modern Selamat yaitu: SMP PMS rangkap Madrasah Wustha, SMA PMS rangkap Madrasah Ulya, SMP Uanggulan PMS rangkap Madrasah Wustha, SMA Unggulan PMS rangkap Madrasah Ulya.

Untuk menunjang keberhasilan mewujudkan visi dan misinya, Pondok Modern Selamat memili berbagai fasilitas penunjang, antara lain: Masjid Sualman, Aula Pondok Pesantren, Asrama Santri Putra dan Putri, Gedung dan Ruang Kelas, Laboratorium Komputer, Laboratorium IPA, Perpustakaan, Kantin dan koperasi Sekolah, Lapangan Olah Raga, Kolam renang, Ruang Kesehatan putra dan purtri, Ruang Makan Santri, Tempat Isi 
Ulang Air Mineral, Area Parkir, Taman dan Gazebo, Wifi Area, Joglo-joglo pertemuan dan, Auditorium.

Selain berbagai fasilitas penunjang tersebut, Pondok Pesantren Modern Selamat juga didukung oleh sumber daya manusia yang memadai baik yang berupa pegawai tetap maupun tegana yang diperbantukan dari luar lingkungan pondok pesantren. Adapun beberapa SDM penunjang Pondok Pesantren Modern Selamat antara lain: Pengelola Yayasan Berjumlah 6 Orang, Guru Agama 28 Orang, Guru SMA 48 Orang, Guru SMP 49 orang, Satpam 24 Orang, dan Tenaga Kesehatan 6 Orang.

\section{Pembahasan}

Berdasarkan hasil dan diskusi dalam penelitian tentang Implementasi Kebijakan Pencegahan dan Penanganan Covid-19 di Pondok Pesantren Modern Selamat Kabupaten kendal, Jawa Tengah ini, dapat dijabarakan sebagai berikut:

\section{a. Menghentikan Laju Penyebaran Dan Transmisi/ Penularan Covid-19}

Upaya dalam melakukan pencegahan penyebaran dan penularan Covid-19 di Pondok Pesantren Modern Selamat mengacu pada buku pedoman pencegahan dan pengendalian Corona Virus Disease (Covid-19) Revisi Ke-5 yang diterbitkan oleh Kementrian Kesehatan Republik Indonesia dengan berbagai kegiatan yang dilakukan, antara lain: Pembentukan Satgas Penanganan Covid-19 yang dalam hal ini diketuai oleh Saudara Alif Setiawan, melakukan pembenahan fasilitas PMS yang sesuai dengan standar protokol kesehatan Covid-19.

\section{b. Upaya Perlindungan Kesehatan}

Upaya perlindungan kesehatan dalam penanganan Covid-19 ini, terbagi menjadi tiga bagian penting yaitu:

\section{1) Upaya Pencegahan (Prevent)}

Upaya pencegahan yang dilakukan oleh Pondok Pesantren Modern Selamat sesuai dengan kebijakan yang diambil oleh pemerintah yang terdiri atas tindakan berikut: Kegiatan promosi kesehatan merupakan salah satu bentuk kegiatan pencegahan berdasarkan buku panduan yang diterbitkan oleh Kementerian Kesehatan Republik Indonesia, kegiatan promosi kesehatan dalam rangka melakukan perlindungan kesehatan di lingkungan Pondok Pesantren Selamat dilakukan melalui berbagai media informasi untuk memberikan pengertian dan pemahaman bagi semua orang khususnya Sumber Daya Manusia yang terkait langsung dengan Pondok Modern Selamat, terkait perihal tersebut beberapa media promosi kesehatan yang berupa spanduk-spanduk informasi pencegahan Covid-19 yang tersebar di sebagian besar lingkungan maupun gedung Pondok Modern Selamat seperti pada gambar berikut: 


\section{Gambar 1. Spanduk Himbauan Mematuhi Protokol Kesehatan}
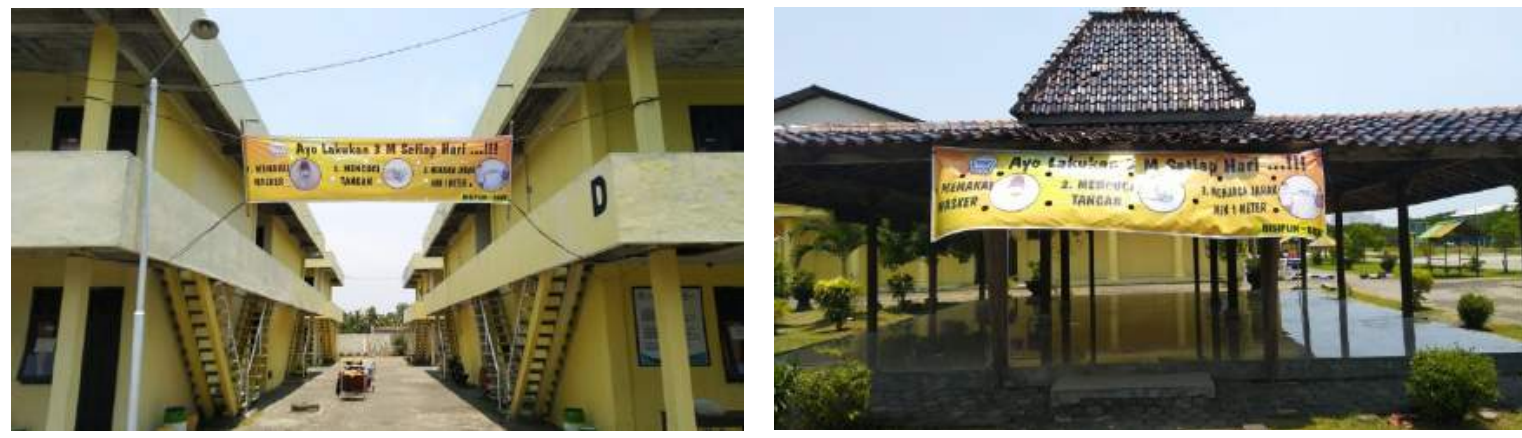

Sumber: Dokumentasi PMS

Kegiatan Perlindungan (Protect) merupakan kegiatan perlindungan atas penyebaran Covid-19. Di lingkungan Pondok Pesantren Modern Selamat dilakukan melalui berbagai upaya, antara lain: Pertama, penyediaan sarana cuci tangan dengan memakai sabun yang mudah di akses dan memenuhi standar atau penyediaan handsanitizer. Dalam kaitan ini, Pondok Pesantren Moderen Selamat menyediakan sarana cuci tangan yang ditempatkan di semua bagian yang diletakkan di bagian depan setiap gedung yang ada di lingkungan Pondok Modern Selamat, Baik Gedung Kantor, Sekretariat Yayasan, Gedung Kelas, Asrama Santri, Masjid, Serta di Pintu Masuk Lingkungan Pondok Modern Selamat semua tersedia pasilitas cuci tangan sesuai dengan buku pedoman pencegahan dan pengendalian Corona Virus Disease (Covid-19) yang diterbitkan oleh Kementrian Kesehatan Republik Indonesia.

\section{Gambar 2. Sarana Cuci Tangan PMS}
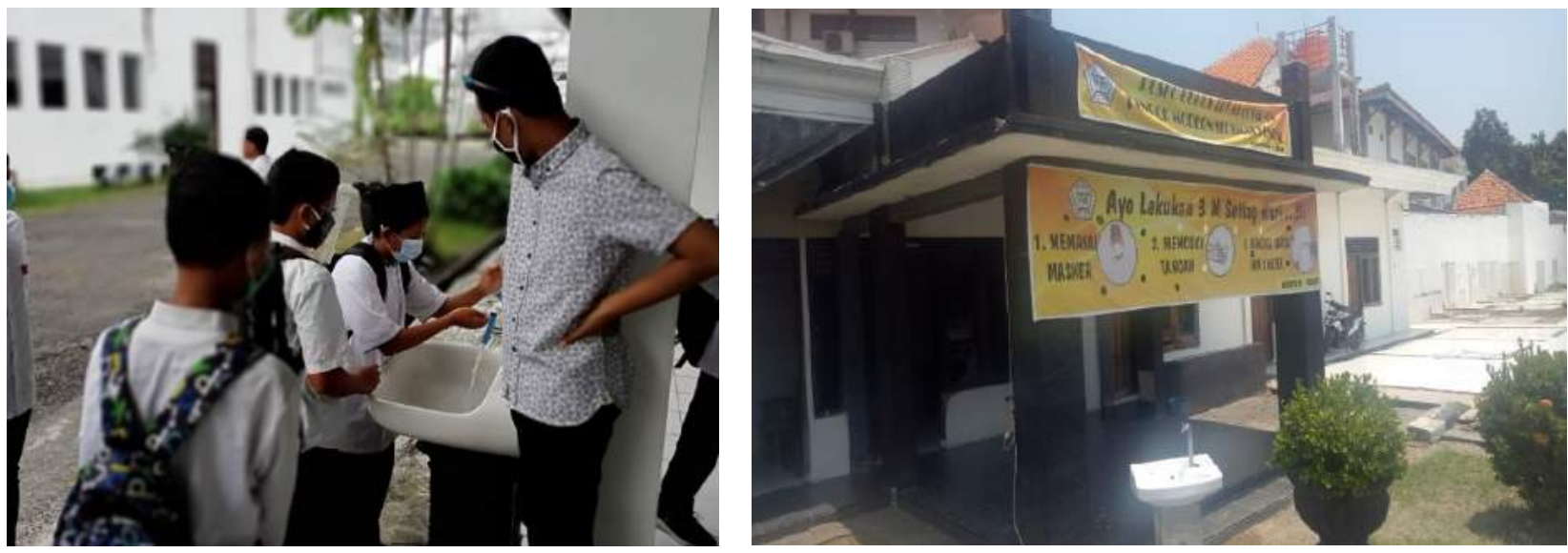

Sumber: Dokumentasi PMS 
Kedua, upaya penapisan kesehatan orang yang akan masuk ke wilayah Pondok Pesantren Modern Selamat yang dilakukan dengan bentuk kegiatan pemeriksaan suhu tubuh oleh petugas keamanan di lingkungan Pondok Pesantren Selamat dan memberikan fasilitas pemeriksaan kesehatan (Swab Test) yang dilakukan rutin setiap bulan bagi semua Sumber Daya Manusia (SDM) yang ada di lingkungan Pondok Pesantren Modern Selamat. Kegiatan pemeriksaan kesehatan yang dilakukan bekerjasama dengan Rumah Sakit Islam kendal dan beberapa klinik kesehatan yang ada di Kabupaten kendal maupun Kabupaten Batang.

\section{Gambar 3. Pemeriksaan Suhu Tubuh Oleh Santri}

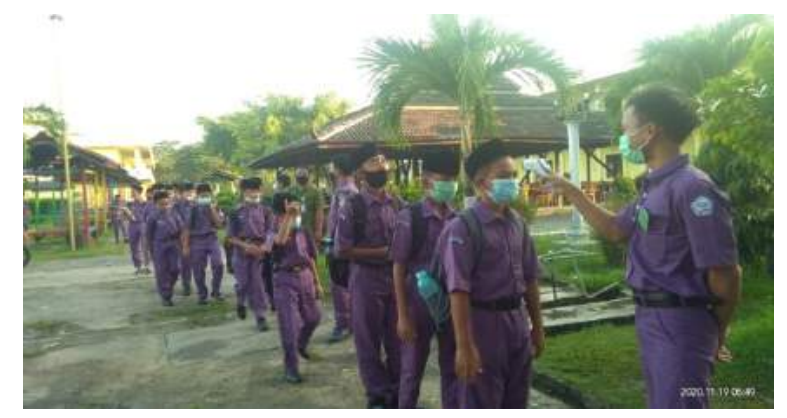

Sumber: Dokumentasi PMS

\section{Gambar 4. Pemeriksaan Suhu Tubuh Oleh Pengasuh PMS}

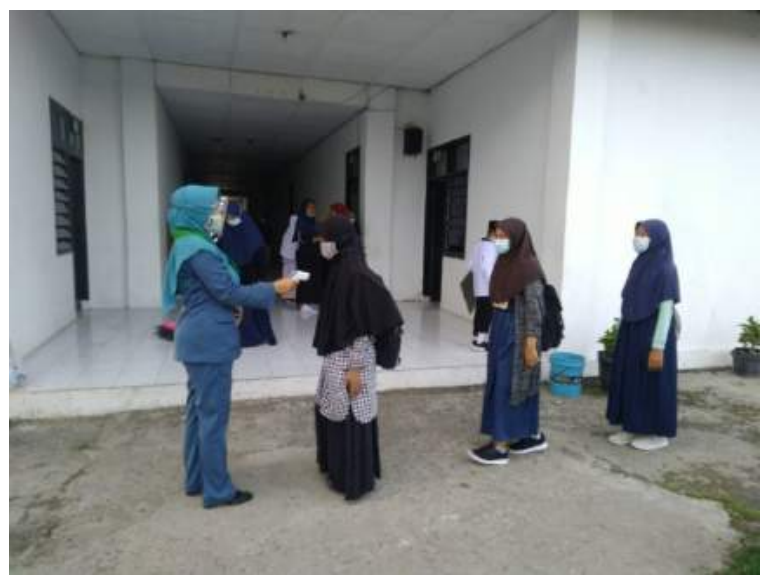

Sumber: Dokumentasi PMS 


\section{Gambar 5. Pemeriksaan Kesehatan (Swab Test)}

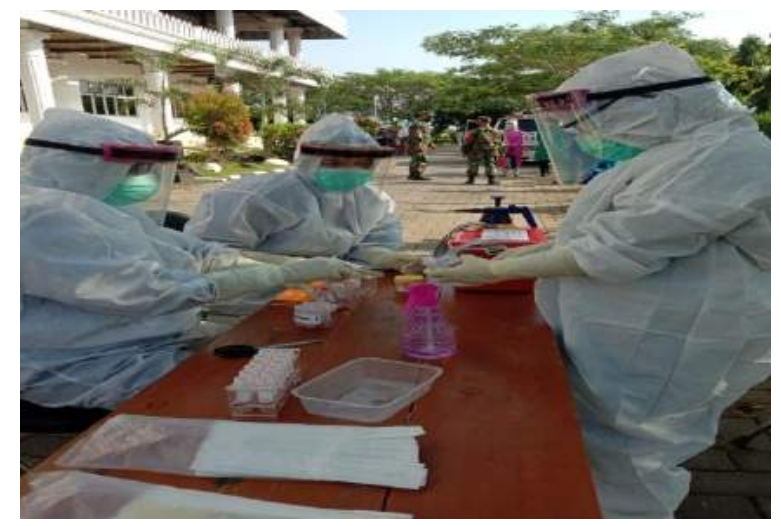

Sumber: Dokumentasi PMS

\section{Gambar 6. Contoh Hasil Swab Test PMS}

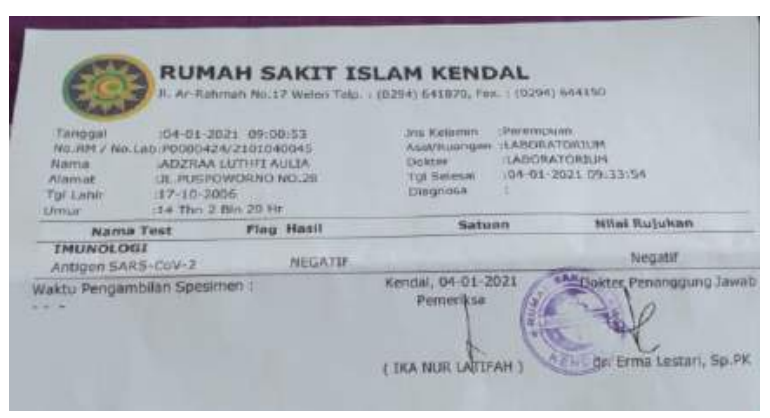

Sumber: Dokumentasi PMS

Ketiga, Pengaturan jaga. Berkaitan dengan protokol kesehatan yang ketiga ini, pengaturan jarak dilakukan pada semua fasilitas yang ada di Pondok Modern Selamat, mulai dari pemberian jarak jamaah di masjid PMS, Ruang kelas, Aula, Auditorim, kantin dan berbagai fasilitas lainnya sehingga tujuan utama melakukan penekanan dan pengendalian terhadap penularan Covid-19 dapat teratasi.

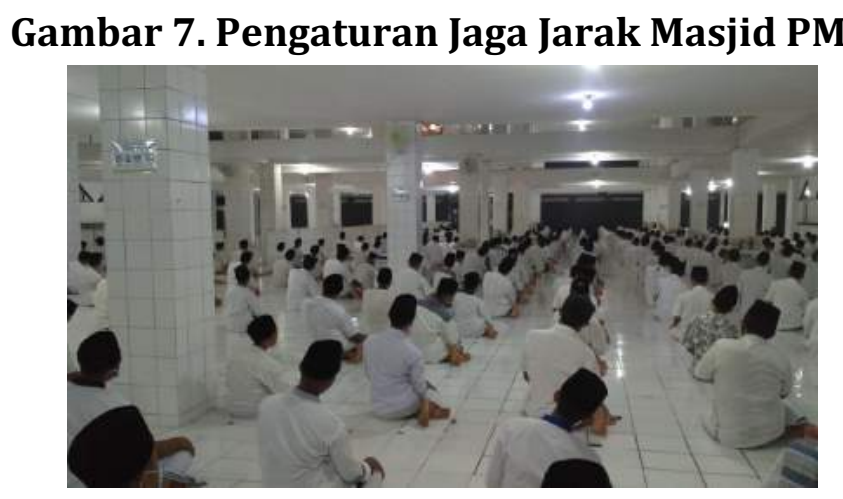


Sumber: Dokumentasi PMS

\section{Gambar 8. Pengaturan Jaga Jarak di Auditorium PMS}

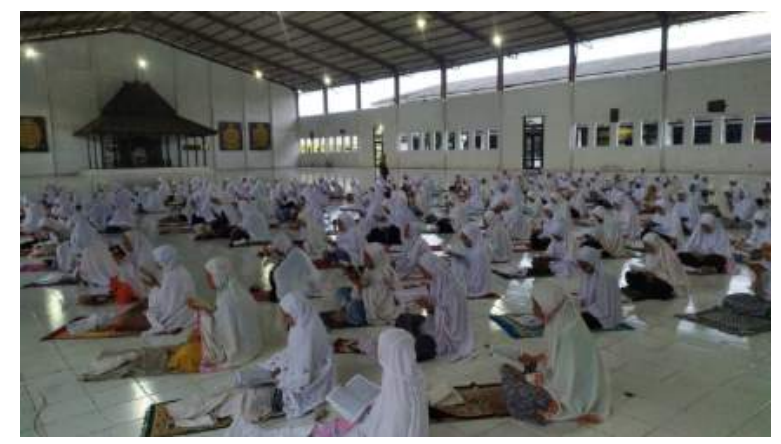

Sumber: Dokumentasi PMS

\section{Gambar 9. Pengaturan Jaga Jarak di Pasilitas Olahraga PMS}

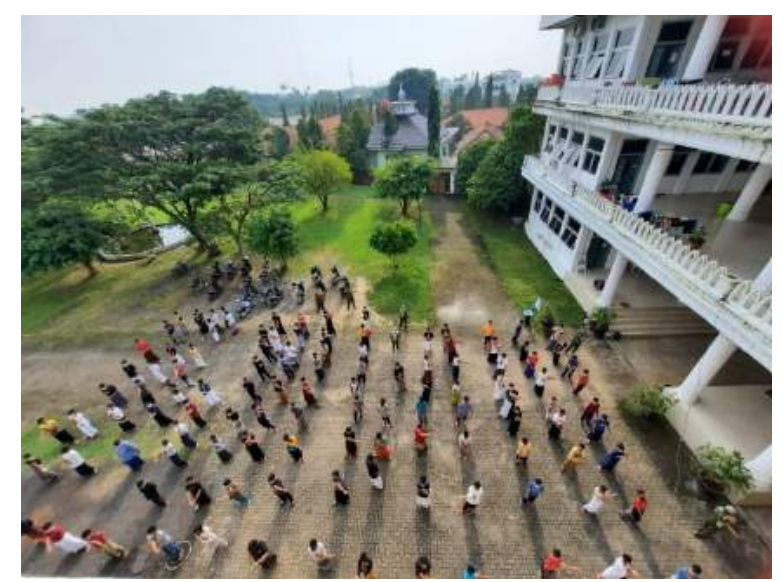

Sumber: Dokumentasi PMS

Keempat, Melakukan disinfeksi terhadap permukaan, ruangan, fasilitas, dan peralatan yang ada di Pondok Modern Selamat secara berkala. dalam hal ini kegiatan tersebut dilakukan oleh petugas kebersihan PMS bekerjasama dengan petugas kesehatan milik PMS. Kelima, Menegakkan kedisiplinan kepada semua sumber daya manusia yang ada di lingkungan Pondok Modern Selamat dengan selalu memperhatikan protokol kesehatan sesuai standard yang telah ditentukan oleh pemerintah.

\section{Upaya Penemuan Kasus (detect)}

Upaya penemuan kasus sesuai dengan buku pedoman pencegahan dan pengendalian Covid-19 yang diterbitkan oleh Kementerian Kesehatan Republik Indonesia dapat dilakukan dengan cara-cara seperti berikut ini: Pertama, Melakukan deteksi dini untuk mengantisipasi penyebaran Covid-19 di lingkungan Pondok Pesantren Modern Selamat melalui upaya koordinasi dengan dinas kesehatan setempat, dalam hal ini 
koordinasi selalu dilakukan antara Gugus Tugas Penanganan Covid-19 Pondok Modern Selamat dengan Gugus Tugas Penanganan Covid-19 Kabupaten Kendal.

\section{Gambar 10. Pemantauan Oleh Gugus Tugas Penangan Covid-19 Kabupaten Kendal}

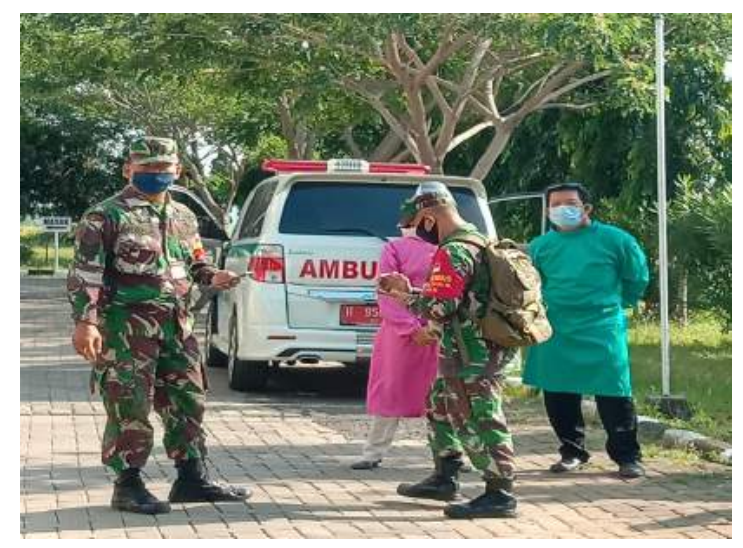

Sumber: Dokumentasi PMS

\section{Gambar 11. Pencanangan PMS Sebagai Ponpes Siaga Candi Polres Kendal}

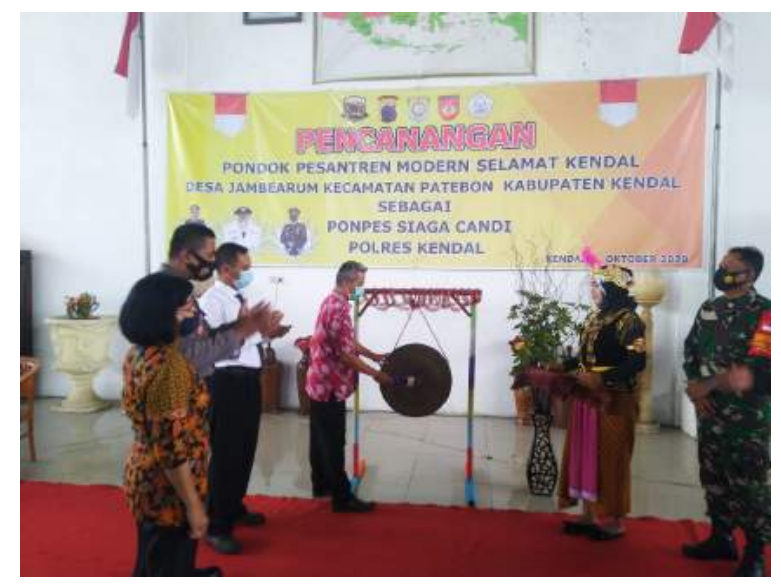

Sumber: Dokumentasi PMS

Kedua, Melakukan pemantauan kondisi kesehatan (gejala demam, batuk, pilek, nyeri tenggorokan, dan/atau sesak napas) terhadap semua Sumber Daya Manusia yang ada di lingkungan Pondok Pesantren Modern Selamat. Pemantauan ini dilakukan rutin oleh petugas kesehatan yang dimiliki oleh Pondok Modern Selamat terhadap semua sumber daya manusia yang ada di lingkungan Pondok Pesantren Modern Selamat. 


\section{Gambar 12. Pemantauan Kondisi Kesehatan Santri Wanita}

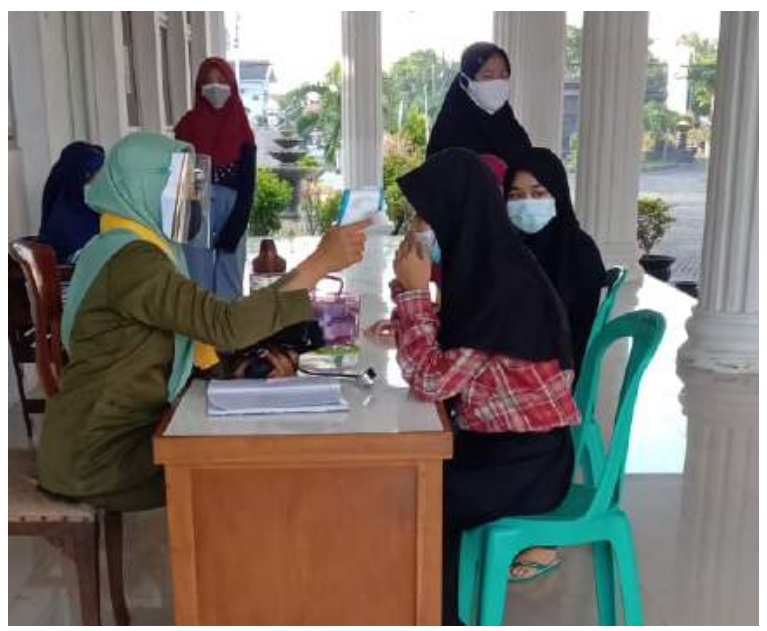

Sumber: Dokumentasi PMS

\section{Gambar 13. Pemantauan Kondisi Kesehatan Santri Pria}

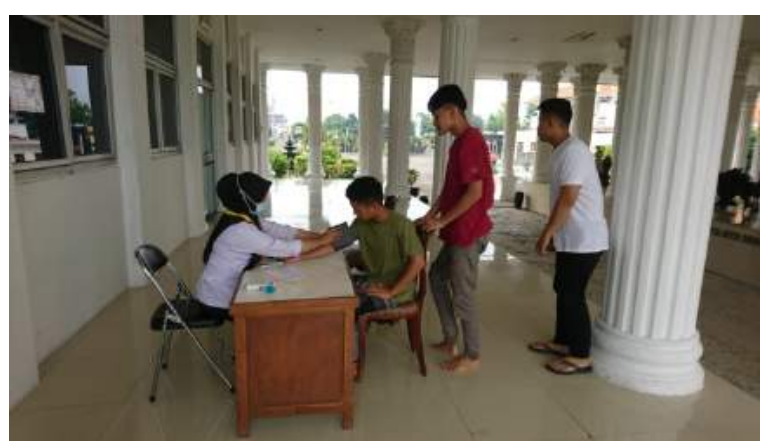

Sumber: Dokumentasi PMS

\section{2) Unsur Penanganan Secara Cepat dan Efektif (Respond)}

Melakukan penanganan untuk mencegah terjadinya penyebaran yang cukup luas, antara lain dapat dilakukan dengan cara berkoordinasi pada fasilitas pelayan kesehatan yang ada di lingkungan PMS maupun berkoordinasi dengan Dinas Kesehatan Setempat. Untuk penanganan secara cepat dan efektif ini, Pondok Pesantren Modern Selamat memiliki fasilitas pelayanan kesehatan yang ada dilingkungan PMS dengan ditunjang oleh tenaga kesehatan yang memadai. Penanganan kesehatan terkait respond adanya Covid-19 di lingkungan Pondok Pesantren Modern Selamat meliputi:

Pertama, Pembatasan Fisik dan Pembatasan Sosial. Untuk penanganan terkait respond yang pertama ini, sudah dilakukan dan diberlakukan pada semua unsur terkait 
didalam lingkungan Pondok Modern Selamat khususnya kegiatan physical distancing dan penggunaan alat pelindung wajah para petugas yang berinteraksi dengan banyak orang. Selain itu, bentuk pelayanan yang menerapkan protokol kesehatan physical distancing juga di lakukan pada sebagian besar pos pelayanan di lingkungan Pondok Pesantren Selamat. Perihal tersebut ditunjukkan dengan adanya penyekatan jarak antara petugas pelayanan dengan mengikuti standar yang dianjurkan seperti pada fasilitas pelayanan dibawah ini:

\section{Gambar 14. Penyekatan Ruang Pelayanan}

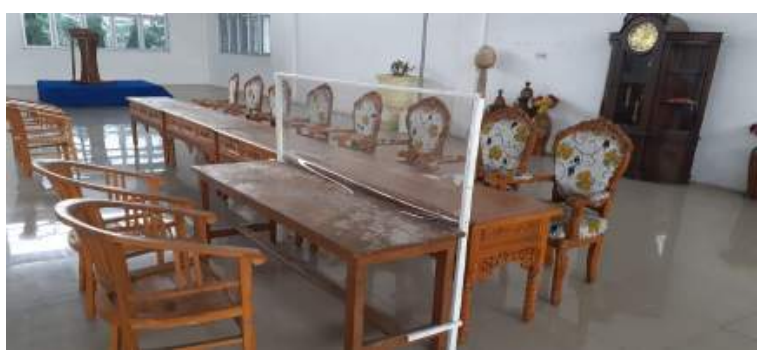

Sumber: Dokumentasi PMS

\section{Gambar 15. Penggunaan Penutup Wajah Oleh Guru PMS}

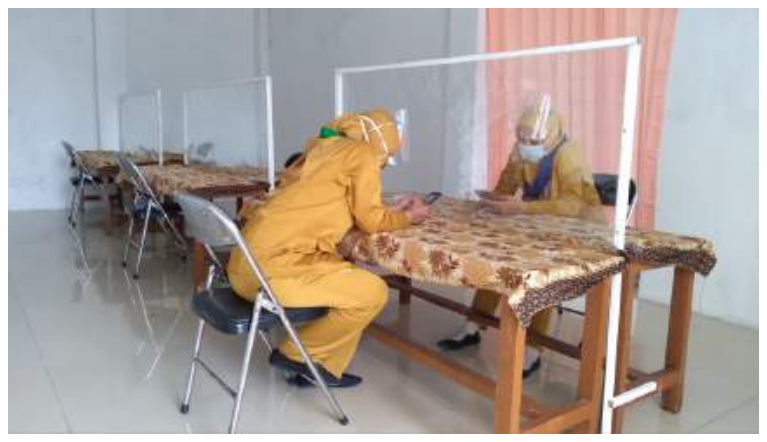

Sumber: Dokumentasi PMS

\section{Gambar 16. Penyekatan Ruang Pelayanan Orang Tua dan Santri}

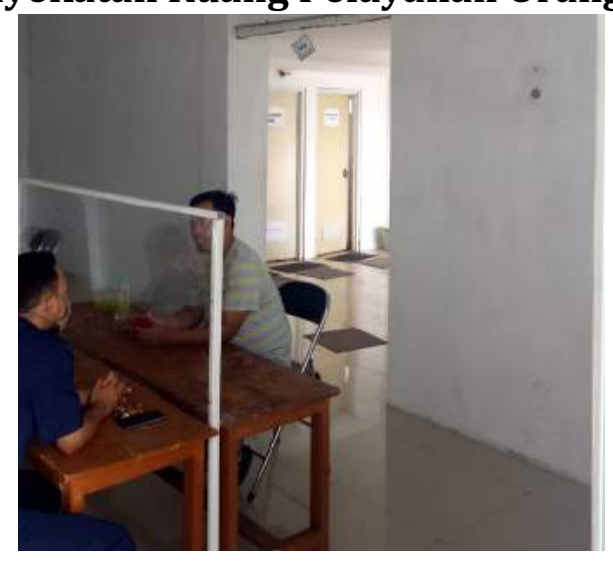


Kedua, penerapan etika batuk dan bersin. Pada unsur yang kedua ini, semua hal yang terkait dengan penerapan etika batuk dan bersin sesuai dengan buku pedoman pencegahan Covid-19 yang diterbitkan oleh Kementerian Kesehatan Republik Indonesia sudah disosialisasikan terhadap semua unsur sumber daya manusia yang ada di lingkungan Pondok Modern Selamat.

Ketiga, Isolasi Mandiri. Isolasi mandiri atau perawatan dirumah sesuai dengan buku pedoman pencegahan dan pengendalian Covid-19 dari Kementerian Kesehatan Republik Indonesia dilakukan terhadap orang yang bergejala ringan terpapar Covid-19 dan tanpa kondisi penyerta seperti (penyakit paru, jantung, ginjal dan kondisi immunocompromise). Tindakan ini dapat dilakukan pada pasien dalam pengawasan, orang dalam pemantauan, dan kontak erat yang bergejala dengan tetap memperhatikan kemungkinan perburukan.

Pada unsur yang ketiga ini, isolasi mandiri di lingkungan Pondok Modern Selamat diberlakukan terhadap semua unsur sumber daya manusia yang ada di lingkungan Pondok Modern Selamat khususnya bagi SDM yang memiliki riwayat perjalanan dari luar daerah. Pemberlakukan unsur yang ketiga ini dilakukan pada saat awal Pondok Modern Selamat membuka akses untuk melakukan pembelajaran tatap muka, sehingga isolasi mandiri diberlakukan bagi semua SDM khususnya santri yang berasal dari luar daerah Kabupaten Kendal dan Batang.

Pada penelitian ini, Saudara Alif Setiawan yang merupakan pengelola Pondok Modern Selamat menuturkan bahwa awal mula PMS membuka akses untuk melakukan pembelajaran tatap muka yaitu pada 5 Agustus 2020 tercatat 800 Orang dari total 1.476 Santri menghendaki pembelajaran tatap muka sehingga Pondok modern selamat mengakomodir harapan para santri tersebut dengan menyiapkan berbagai fasilitas yang sesuai dengan standar pelayanan pada Era New Normal.

Dalam pelaksanaanya, sebagaimana informasi yang kami peroleh dari saudara alif Setiawan tersebut, setiap santri yang baru tiba akan di karantina secara mandiri di Rumah Karantina yang telah disediakan oleh Pondok Pesantren Modern Selamat dengan ditunjang fasilitas pemeriksaan kesehatan yang memadai dan petugas pelaksanaan isolasi yang cukup sehingga proses isolasi berjalan dengan sukses.

\section{Gambar 17. Petunjuk Arah Ruang Karantina}

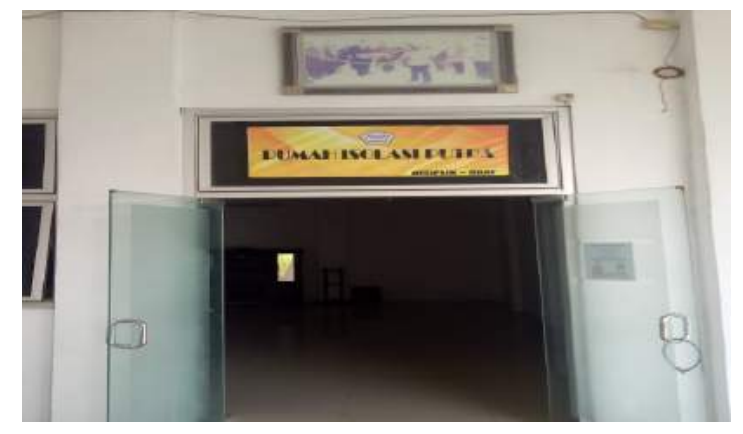




\section{Gambar 18. Fasilitas Pemeriksaan Kesehatan PMS}

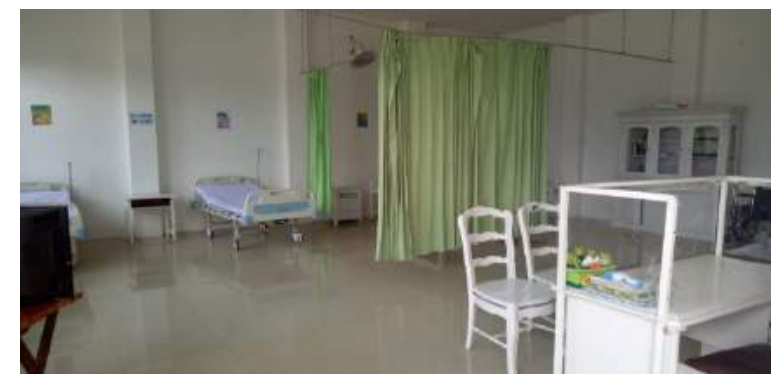

Sumber: Dokumentasi PMS

Keempat, Pelaksanaan Tindakan Karantina Terhadap Populasi Beresiko. Mengutip buku pedoman pencegahan dan pengendalian Covid-19 yang di terbitkan oleh Kementerian Kesehatan, Tindakan karantina dilakukan untuk mengurangi risiko penularan dan identifikasi dini Covid-19 melalui upaya pemisahan individu yang sehat dengan yang memiliki riwayat kontak, berpergian ke wilayah yang sudah terjadi transmisi lokal atau individu yang telah terdeteksi memiliki gejala terpapar Covid-19.

Berkaitan dengan perihal karantina di Pondok Pesantren Modern Selamat terjadi setelah adanya penemuan klaster pondok pesantren dengan kronologis adanya penemuan salah satu santri asal Jepara yang positif terpapar Covid-19 dan dilakukan proses tracing terhadap semua SDM yang ada di Pondok Modern Selamat dengan hasil ditemukan sebanyak 12 santri lainnya juga Positif Terpapar Covid-19.

Dengan adanya hasil tracing tersebut maka, Gugus Tugas Penanganan Covid-19 Pondok Modern Selamat bekerjasama dengan Gugus Tugas Penanganan Covid-19 Kabupaten kendal melakukan isolasi terhadap para santri tersebut. Isolasi yang dilakukan dibagi menjadi dua lokasi berbeda berdasarkan kategori penyebaran Covid-19nyang berbeda yaitu kategori Orang Tanpa Gejala (OTG) dan kategori terpapar dengan gejala. Isolasi santri dengan kategori terpapar dengan gejala dilakukan di Rumah Sakit Darurat Covid-19 (RSDC) Kendal sedangkan untuk kategori OTG isolasi dilakukan di Ruang Karantina yang ada di lingkungan Pondok Modern Selamat. 


\section{Gambar 19. Penunjuk Arah Ruang Karantina PMS}

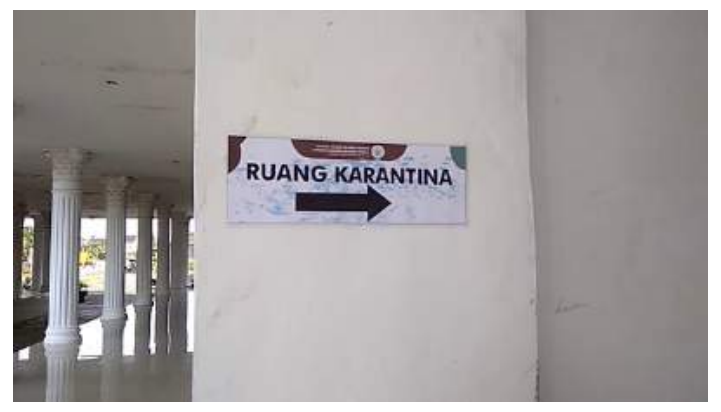

Sumber: Dokumentasi PMS

\section{Gambar 20. Peninjauan Ruang Karantina PMS Oleh Gugus Tugas Covid-19}

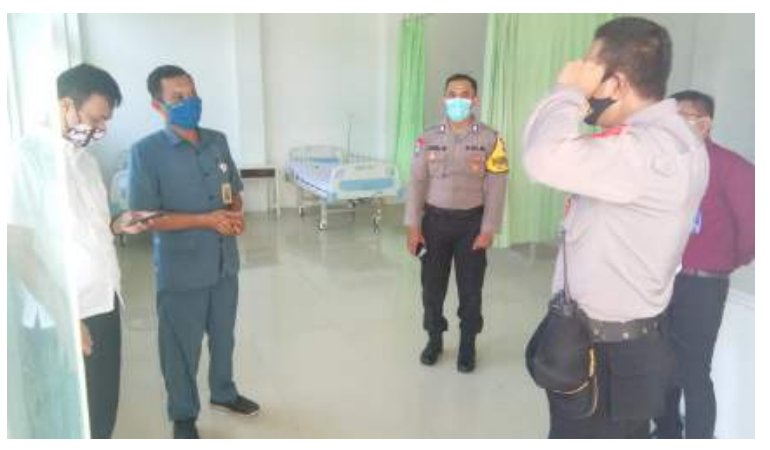

Sumber: Dokumentasi PMS

Berdasarkan penuturan dari Saudara Alif Setiawan yang dalam hal ini sebagai ketua Gugus Tugas Penanganan Covid-19 Pondok Pesantren Modern Selamat, beliau menuturkan bahwa karantina yang dilakukan di ruang karantina milik Pondok Modern Selamat bekerja sama dengan petugas kesehatan yang dari Gugus Tugas Penanganan Covid-19 Kabupaten Kendal. Dalam program karantina yang ada di lokasi karantina milik PMS, petugas kesehatan khususnya dokter hanya dihadirkan pada saat waktu pemeriksaan. Untuk perawatan rutin dan kontrol terhadap pasien dikelola oleh gugus tuga penanganan Covid19 Pondok Modern Selamat bersama dengan tenaga kesehatan yang dimilki oleh Pondok Modern Selamat. 


\section{Gambar 21. Tata Tertib Karantina PMS}

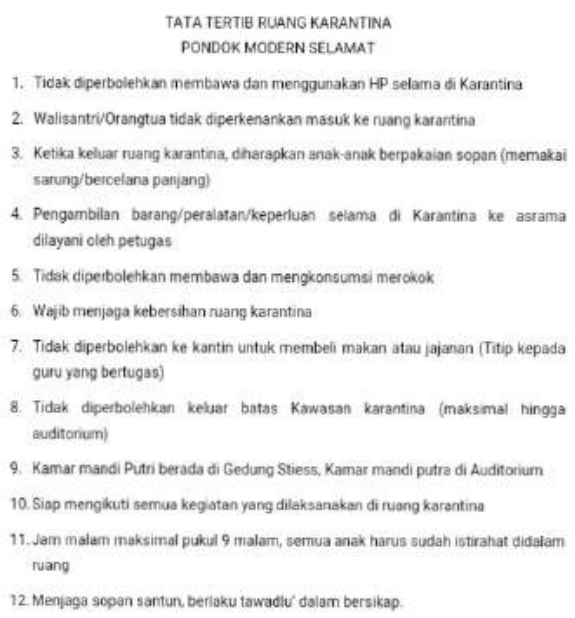

Sumber: Dokumentasi PMS

\section{Gambar 22. Ruang Pemeriksaan Pasien Covid-19}

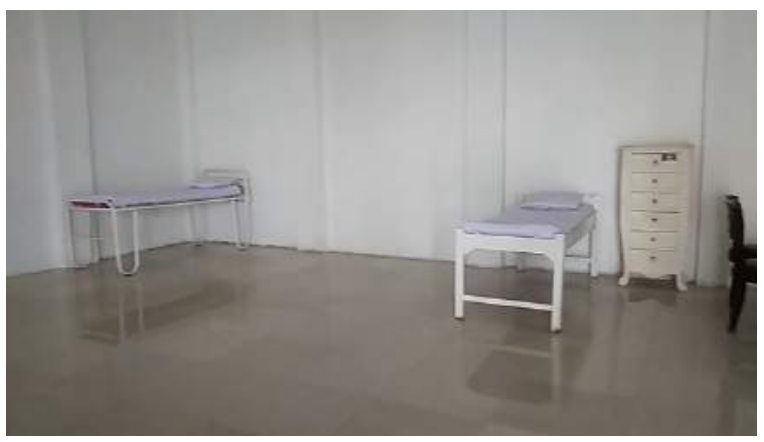

Sumber: Dokumentasi PMS

Berdasarkan hasil pembahasan mengenai upaya perlindungan kesehatan terhadap semua sumber daya manusia yang ada di lingkungan Pondok Modern Selamat berhasil dilakukan. Keberhasilan tersebut terjadi karena adanya fasilitas penunjang dan tenag kesehatan serta program pencegahan yang disediakan oleh Pondok Modern Selamat yang dikelola dengan berpedoman pada buku panduan dan anjuran serta kebijakan yang telah diambil oleh pemerintah, baik pemerintah pusat maupun pemerintah daerah khususnya Pemerintah Kabupaten Kendal. Keberhasilan tersebut terbukti dengan hasil bahwa semua santri dan SDM yang ada di lingkungan Pondok Modern Selamat terbebas dari Covid-19 dan kegiatan belajar dan mengajar serta aktifitas lainnya di lingkungan Pondok Pesantren Selamat dapat dijalankan. 


\section{c. Menyediakan Fasilitas Pelayanan Kesehatan}

Berdasarkan buku pedoman pencegahan dan pengendalian Covid-19 yang diterbitkan oleh Kementrian Kesehatan serta berbagai kebijakan lainnya yang diambil oleh pemerintah, Pondok Pesantren Modern Selamat telah menyediakan fasilitas pelayanan kesehatan yang memadai sebagai bentuk dukungan atas upaya penekanan terhadap penyebaran Covid-19 khususnya di lingkungan Pondok Modern Selamat.

Dalam rangka melakukan pelayanan kesehatan terhadap pasien Covid-19 di lingkungan Pondok Modern Selamat, petugas kesehatan yang dimiliki oleh PMS selalu bekerja sama dengan gugus tugas penanganan Covid-19 Kabupaten Kendal. Setiap ada penemuan kasus terpapar Covid-19 dan kegiatan penanganan atas kasus tersebut selalu di laporkan secara Up to date Kepada Gugus Tugas Penangan Covid-19 Kabupeten Kendal.

\section{Gambar 23. Fasilitas Pelayanan Kesehatan PMS}

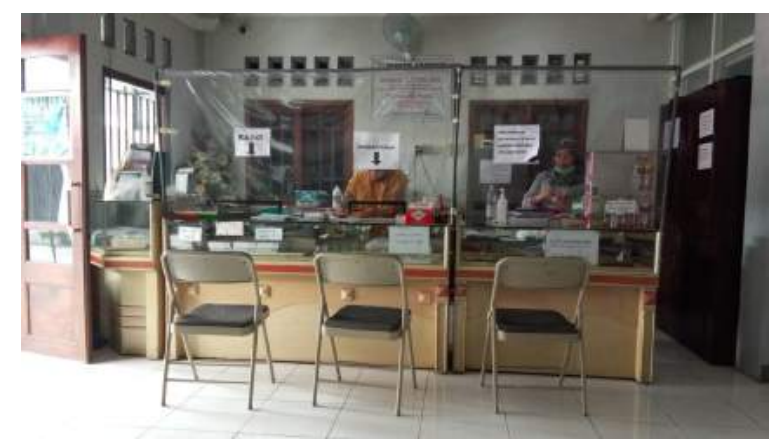

Sumber: Dokumentasi PMS

\section{d. Meminimalkan Dampak Dari Pandemi Covid-19 Terhadap Pelayanan Sosial}

Upaya meminimalisir dampak pandemi Covid-19 terhadap pelayanan yang ada di lingkungan Pondok Pesantren Modern Selamat pasca dibukanya akses pembelajaran tatap muka di lingkungan Pondok Modern Selamat dilakukan dengan berpedoman pada anjuran pemerintah berdasarkan kebijakan yang telah di implementasikan maupun buku pedoman yang dikeluarkan oleh Kementerian Kesehatan. Berbagai upaya yang dilakukan antara lain:

Pertama, menutup akses menuju Pondok Modern Selamat. Dalam hal ini, Upaya pencegahan penularan Covid-19 di lingkungan PMS salah satunya dilakukan dengan menutup akses kunjungan bagi para orang tua santri serta menutup pintu bagi santri untuk berpergian atau kembali ke rumah saat libur tiba. Berdasarkan informasi yang kami peroleh dari para pengasuh PMS disebutkan bahwa ketika ada kunjungan dari oreng tua santri, pelayanan dan pertemuan akan dilakukan di ruang khusus yang disediakan dengan mematuhi standar-standard protokol kesehatan yang dianjurkan sehingga dapat meminimalisisr dampat penyebaran Covid-19 di lingkungan PMS. 
Kedua, Menyediakan fasilitas yang dilengkapi dengan protokol kesehatan yang memadai, sehingga dapat meminimalisir terjadi penularan atas penemuan kasus terpapar Covid-19 di lingkungan Pondok Pesantren Modern Selamat. Ketiga, melakukan pemeriksaan berkala bagi semua SDM yang ada di lingkungan Pondok Pesantren Modern Selamat.

\section{Kesimpulan}

Berdasarkan hasil dan pembahasan dalam penelitian ini dapat disimpulkan bahwa Pondok Pesantren Modern Selamat telah berhasil mengimplementasikan kebijakan terkait pencegahan dan penanganan Covid-19 yang ditandai dengan terpilihnya sebagai pondok dengan pengalaman terbaik penanganan covid-19 se-Jawa Tengah oleh yayasan Setara bekerjasama dengan Lembaga Penelitian dan Pengabdian Kepada Masyarakat Universitas Diponegoro (LPPM Undip) dan Unicef Jawa Tengah. Adapun implementasi yang telah dilakukan antara lain: Pertama, menghentikan laju penyebaran dan transmisi/penularan Covid-19 dengan upaya perlindungan kesehatan yang terbagi menjadi: Upaya pencegahan dengan kegiatan promosi kesehatan, kegiatan perlindungan dengan menyediakan fasilitas yang sesuai dengan protokol kesehatan Covid-19, Upaya penemuan kasus (detect) dengan cara melakukan pemeriksaan suhu tubuh dan swab test, Serta penerapan penanganan secara cepat dan efektif dengan cara pembatasan pisik dan pembatasan sosial, penerapan etika batuk dan bersin, isolasi mandiri, dan pelaksanaan tindakan karantina. Kedua, menyediakan fasilitas pelayanan kesehatan diantaranya: rumah karantina, ruang isolasi dan ruang pemeriksaan kesehatan. Ketiga, Meminimalisir dampak dari pandemi Covid-19 terhadap pelayanan sosial dengan cara menutup akses menuju pondok Pesantren Modern Selamat, menyedikan fasilitas yang dilengkapi dengan protokol kesehatan, melakukan pemeriksaan berkala terhadap semua SDM yang ada di lingkungan Pondok Pesantren Modern Selamat. 


\section{Daftar Pustaka}

Moh. Nazir. 1998. Metode Penelitian. Jakarta: Ghalia Indonesia.

Kementrian Kesehatan. 2020. Pedoman Pencegahan dan Pengendalian Coronavirus Disease (Covid19). Jakarta: Kementerian Kesehatan RI.

Suharto, Edi. (2010). Membangun Masyarakat Memberdayakan Rakyat Kajian Strategi Pembangunan Kesejahteraan Sosial dan Pekerja Sosial. Bandung: Refika Aditama.

Keputusan Presiden Nomor 7 Tahun 2020 tentang Gugus Tugas Percepatan Penanganan Covid-19.

Peraturan Pemerintah (PP) Nomor 21 Tahun 2020 Tentang Pembatasan Sosial Bersekala Besar (PSBB)

Keputusan Presiden Nomor 11 Tahun 2020 tentang Penetapan Kedaruratan Kesehatan Masyarakat Covid-19.

Peraturan Menteri Kesehatan Nomor 9 Tahun 2020 tentang Pedoman Pembatasan Sosial Bersekala Besar dan Rangka Percepatan Penanganan Covid-19.

Keputusan Gubernur DKI Jakarat Nomor 380 Tahun 2020 Tentang Pemberlakuan Pelaksanaan Pembatasan Sosial Bersekala Besar (PSBB) dalam penanganan Corona Virus Disease 2019 (COVID-19) di Provinsi DKI Jakarta.

Perbup Nomor 51 Tahun 2020 Tentang Kewajiban Penggunaan Masker Dan Jaga Jarak Fisik di Kabupaten Kendal kompaspedia.kompas.id (2020, 22 Juni).

Upaya dan Kebijakan Pemerintah Indonesia Menangani Pandemi Covid-19. Diakses pada 5 Mei 2021, dari: $\quad$ https://kompaspedia.kompas.id/baca/paparan-topik/upaya-dan-kebijakanpemerintah-indonesia-menangani-pandemi-covid-19 jatengprov.go.id (2020, 30 Juni).

Program Inovasi di Kabupaten Kendal Kurangi Penyebaran Covid-19. Diakses pada 6 Mei 2021, dari: https://jatengprov.go.id/beritadaerah/program-inovasi-di-kabupaten-kendal-kurangipenyebaran-covid-19/ republika.co.id (2020, 14 Oktober).

Klaster Pesantren dan Sekolah Yang Mengancam Jawa Tengah. Diakses pada 6 Mei 2021, dari: https://www.republika.co.id/berita/qi6iel328/klaster-pesantren-dan-sekolah-yangmengancam-jawa-tengah radarsemarang.jawapos.com. 2020, 22 September. Klaster Ponpes, 16 Posistiv Covid-19. Diakses pada 6 Mei 2020, dari: https://radarsemarang.jawapos.com/berita/jateng/kendal/2020/09/22/klaster-ponpes16-positif-covid-19/) 